\title{
Mirosław Sobecki: Komunikacja międzykulturowa w perspektywie pedagogicznej. Studium z pogranicza polsko-litewsko-biatorusko-ukraińskiego. Warszawa 2016, Wydawnictwo Akademickie „Żak”, ss. 312
}

Pomimo wielu już lat systematycznej refleksji, badań i studiów w zakresie komunikacji międzykulturowej w wielu zagranicznych i krajowych ośrodkach akademickich, problematyka ta ciągle wymaga systematycznego oglądu, refleksji, jak i zabiegów o charakterze edukacyjnym. W istocie dopiero lata 80. XX wieku przyniosły systematyczny rozwój ośrodków i projektów badawczych powodowanych praktycznymi konsekwencjami procesów globalizacji, umiędzynarodowienia oraz wyzwań narastającej interakcji kultur w warunkach szybkiego postępu procesów medializacji i mobilności. I choć początki refleksji i badań nad relacjami kulturowymi sięgają czasów starożytnych i w różnych formach obecna była w myśli społecznej i humanistycznej wielu kultur na przestrzeni wielu wieków jej trwania, podjęta w pracy Mirosława Sobeckiego problematyka komunikacji międzykulturowej zasługuje na uważne rozpoznanie, pogłębienie, rozwój i popularyzację. Niewątpliwie jako bardzo słuszne uznać należy dwa wyjściowe założenia pracy, które określają sposób jej lektury, ale także aplikacji przyjętej metodologii oraz wskazania projektujące dalszy rozwój badań.

Po pierwsze, zainteresowanie, świadomość i wykorzystanie polskich badań w zakresie komunikacji międzykulturowej nie byłoby możliwe bez zasadniczych zmian ustrojowych, które dokonały się w Polsce lat 90. XX wieku i które ciągle dokonują się w sferze demokratyzacji życia społecznego, a co za tym idzie - uwolnienia potencjałów kulturowych, praw do kultywowania tożsamości narodowych, etnicznych, regionalnych, środowiskowych, a w konsekwencji także indywidualnych. Zauważenie tej niedocenianej już często prawdy jest istotnym kontekstem warunkującym nie tylko polityczne, ale w równej mierze etyczne, kulturowe i osobowościowe wymiary rozwoju wrażliwości kulturowej, a następnie międzykulturowej wszystkich uczestników procesu. Uwolnienie podmiotowości społecznej, wspólnotowej i indywidualnej jest być może najistotniejszym dynamizmem rozwojowym, jaki zawiera w sobie komunikacja międzykulturowa, szczególnie jeśli zmierzamy do odsłonięcia jej wymiaru pedagogicznego. Uchwycenie wagi tego aspektu 
pozwala pokonać statyczny charakter studiów deskryptywnych odwołujących się nie tyle do dynamiki perspektywy międzykulturowej, co strukturalnych cech perspektywy wielokulturowej, co umiejętnie zostaje w pracy rozpoznane. Podmiotowość wspólnoty i podmiotowość osoby ludzkiej jest bowiem trudną do przecenienia wartością czasów demokratycznych transformacji którą warto ciągle wzmacniać i wspierać.

Po drugie, Autor bardzo konsekwentnie buduje tezę o nie tylko walorach, ale wręcz konieczności uwzględnienia specyfiki regionalnego, lokalnego, a więc środowiskowego kontekstu procesów, dynamizmów i potencjałów komunikacji międzykulturowej. Dlatego pierwsza część pracy stanowi bardzo wnikliwą analizę trzech ważnych atrybutów tego kontekstu, którymi są:

- pogranicze jako konglomerat specyficznych cech sytuacji komunikacyjnej, w którym procesy interakcyjne, dyfuzyjne i synergetyczne stanowią o jego istocie,

- historyczne uwarunkowania współczesnych procesów komunikacji międzykulturowej wschodnich rejonów Polski oraz jej wschodnich sąsiadów, które budują kody interpretacyjne kompetencji komunikacyjnych ich uczestników,

- cechy dziedzictwa kulturowego o charakterze autochtonicznym, które mogą być wykorzystane w budowaniu współczesnych strategii rozwoju komunikacji międzykulturowej.

Dostrzeżenie specyfiki warunków pogranicza kulturowego jest w analizie procesu, ale i potencjału komunikacji międzykulturowej zabiegiem bardzo istotnym. Komunikacja, jako relacja, odbywać się może w warunkach bardzo odmiennych. Inaczej dokonuje się w sytuacji doraźnej interakcji kultur, które nie mają istotnych powiązań, zapożyczeń i które nie wchodzą w relacje długoterminowe. Odmienną charakterystyką wykazuje się komunikacja zbudowana i budująca wielorakie sieci powiązań. Nie bez znaczenia są także rodzaje konkretnych treści angażowanych w proces wymiany komunikacyjnej. Dlatego wielkim walorem pracy jest analityczny opis procesów komunikacji międzykulturowej w sytuacji pogranicza, co stanowić może uniwersalny wkład w teorię tego zjawiska jako takiego.

Trudną do przecenienia wartością książki jest analiza kulturowej zawartości symbolicznego uniwersum pogranicza dawnej i współczesnej Rzeczypospolitej jako autonomicznego czynnika dawnych i współczesnych procesów komunikacyjnych. Z tej perspektywy praca stanowi niezwykłe barwny i poglądowy obraz zarówno procesów, jak i znaczących wydarzeń, treści oraz wątków kulturowych przenikających się kultur. Z wielu względów uznać ją można za 
przełamującą wiele stereotypów poprzez przywołanie niezwykle celnie zidentyfikowanych, konceptualnych i symbolicznych komponentów dziedzictwa kulturowego judaizmu, religii chrześcijańskich oraz wielokulturowego obszaru Polski jagiellońskiej. Bardzo cennym fragmentem tej części pracy jest ukazanie współczesnych inspiracji tą częścią międzykulturowego dziedzictwa doby Jagiellonów widocznego $\mathrm{w}$ wielkim dorobku intelektualnym i duchowym Pawła Włodkowica. Jego współczesne odczytanie jest o tyle interesujące, iż ukazuje nie tylko wagę tolerancji religijnej, ale rosnące znaczenie problematyki prawa narodów, które w realiach współczesnych społeczeństw wielo- i transnarodowych nabierają znaczenia praw kulturowych. Co istotne, istotą tej wielowątkowej koncepcji, która może być drogą rozwiązywania wielu współczesnych konfliktów etnicznych i kulturowych, jest odwołanie się do fundamentalnej podstawy jakkolwiek pojętej wzajemności, symetrii i ładu w relacjach międzykulturowych, jaką jest poszanowanie godności człowieka i wspólnoty oraz respektu w stosunku do „prawa naturalnego”, który gwarantuje poszanowanie wszystkich praw człowieka. Zawarte w tej koncepcji inspiracje są szczególnie obiecujące właśnie z perspektywy pedagogicznej, odwołują się bowiem nie tylko do analitycznego rozpoznania reguł i praw komunikacji, ale określają jej normy, powinności, a więc stanowią powiązanie z problematyką teleologicznej (celowościowej) funkcji skutecznie pojętej edukacji.

Nie bez znaczenia w recenzowanej pracy jest sposób rozumienia samego pojęcia kultury. Określa ono bowiem, jak słusznie podkreśla to Autor, nie tylko sposób rozumienia samego procesu komunikacji i relacji międzykulturowych, ale także jego cele, rodzaj doświadczania i konsekwencje w tworzeniu oznak tożsamości. „Spośród wszelkich możliwych ujęć na potrzeby analizowanej tu perspektywy wybieram - pisze Autor - to, które każe patrzeć na kulturę jako system znakowy. Semiotyczne ujmowanie kultury jest najbliższe absolutnemu rdzeniowi procesów komunikowania. Rozpoznawanie znaczeń tkwi bowiem u podstaw interakcji międzyludzkich. Zaś wspólnota znaczeń stanowi nie tylko fundament porozumiewania się, ale także należy do rudymentów kształtowania się zbiorowej tożsamości” (s. 16).

Perspektywa semiotyczna niejednokrotnie wykazywała swoje walory w rozumieniu podstawowych problemów kultury. W istocie Autor idzie w praktyce znacznie dalej. Jeden z najważniejszych rozdziałów książki, który najbardziej rozwija pedagogiczną perspektywę rozumienia komunikacji międzykulturowej, to rozdział o tytule Aksjologia relacji międzykulturowych. W nim to właśnie przedstawione są „kategorie postaw”, bezpośrednio sprowadzone do wartości, którymi są: 
- Kwestia symetrii w relacjach międzykulturowych;

- Relatywizm kulturowy;

- Kategorie postaw w komunikowaniu międzykulturowym:

- tolerancja w wąskim rozumieniu,

- zainteresowanie odmiennością jako wartością,

- dialog kulturowy jako wartość i działanie,

- symbioza kulturowa jako wartość,

- przyjmowanie perspektywy Innego.

Warto zauważyć, iż niektóre z wymienionych problemów to kluczowe kompetencje międzykulturowe. Perspektywa semiotyczna zostaje więc uzupełniona perspektywą aksjologiczną. Wskazuje na nią bezpośrednio przywołana w pracy Antonina Kłoskowska, która pozostawiła w polskiej myśli humanistycznej własną szkołę socjologii kultury, przywołując za Stefanem Czarnowskim, Florianem Znanieckim, Stanisławem Ossowskim, Józefem Chałasińskim aksjologiczny wymiar kultury jako dopełniający semiotyczną „redukcję” problemu. Wagę wymiaru aksjologicznego sugerował już Clifford Geertz, twórca antropologii symbolicznej, a sama Kłoskowska, popularyzując pojęcie „kultury symbolicznej”, dokonała już ostatecznej integracji obu tych wymiarów analizy, co okazuje się - jak widać to w literalnej treści pracy Mirosława Sobeckiego - zabiegiem heurystycznie, teoretycznie i metodologicznie wręcz nieodzownym. Podobne wnioski płyną także z klasycznych już analiz dokonanych poprzez twórców takich pojęć jak kompetencja socjolingwistyczna, kompetencja komunikacyjna, czy kompetencja kulturowa. Warto przy tym zwrócić uwagę, że pojęcie i koncepcja kompetencji komunikacyjnej (communicative competence) Della Hymesa jest dla przyjętych założeń pracy szczególnie przydatna. Hymes odwoływał się bowiem do znaczenia wielorakich aspektów kontekstu „sytuacji komunikacyjnej”, uważając, że współdefiniuje on faktyczne funkcje procesu komunikacyjnego o unikalnej często charakterystyce. Sytuacja pogranicza kulturowego spełnia wszystkie cechy opisywane przez inicjowaną przez niego „etnografię komunikowania”. Jeszcze większe możliwości uwrażliwienia na specyfikę kontekstu sytuacyjnego ukazują koncepcje „kompetencji kulturowej”, szeroko wykorzystane także w polskiej tradycji „socjologii kulturowej”, która wyłoniła się na bazie socjologii kultury oraz innych nauk o kulturze.

Rola wartości jest z pewnością jedną z najistotniejszych $\mathrm{w}$ analizie procesu tworzenia, ale i zmiany tożsamości kulturowych, szczególnie gdy podnosimy wymiar tożsamości religijnej. Ten problem także znajduje odzwierciedlenie w bardzo zintegrowanym oglądzie prezentowanym w całokształcie struktu- 
ry pracy. Zjawiska te są przedmiotem analiz w środowisku socjologicznym Katolickiego Uniwersytetu Lubelskiego lat 80. ubiegłego wieku, koncentrując się na społecznej problematyce relacji kultury i religii przez jednego z najwybitniejszych polskich badaczy problemu, a mianowicie Leona Dyczewskiego. Wychodził on z prostego przekonania, iż te same znaczenia mogą mieć bardzo odmienne wartości, a same wartości mogą mieć odmienną lokalizację i odmienną dynamikę w rozwoju osobowości i tożsamości kulturowej człowieka. Z tej perspektywy wymiar transgresyjny i logotwórczy dopełnić powinien nasze rozumienie potencjałów stwarzania, przekształcania i przewartościowań wewnętrznego wymiaru kultury symbolicznej, co obrazować może analiza religijnych aspektów tożsamości kulturowej. Postulat analizy „logotwórczych dynamizmów kultury” był szeroko dyskutowany zarówno w kręgu analiz kulturowych szkoły Dyczewskiego, jak i Kłoskowskiej, która łączyła wiele elementów socjologicznej tradycji środowiska warszawskiego i łódzkiego. Są to obszary integracji analiz kulturowych, psychologicznych, szczególnie psychologii rozwoju (w odróżnieniu od psychologii rozwojowej) i pedagogicznych, istotne w rozpoznawaniu rozwojowych walorów komunikacji międzykulturowej. Zagadnienia te bardzo dobrze określa w przytoczonym powyżej spisie zawartość rozdziału o aksjologii relacji międzykulturowych, co oczywiście dotyczy także komunikacji międzykulturowej. Pośrednio są one także obecne z bardzo wnikliwym rozdziale o interakcjonizmie symbolicznym, w którym elementy wolicjonalne są wręcz warunkiem wchodzenia w interakcje, a więc otwierania na to, co w ich trakcie zostanie wykonstruowane, odnalezione lub zmienione.

Samo pojęcie interakcji, relacji i komunikacji wymaga wszak uważnego dookreślenia. Powstaje bowiem zasadne pytanie, czy każda forma relacji międzykulturowych jest także formą komunikacji. Pedagogiczna perspektywa pracy Mirosława Sobeckiego pozwala dokonać tu stosownych odróżnień. Nie każda forma relacji zakłada bowiem symetrię, wzajemność, uczenie się, otwartość, empatię i budowanie wspólnoty, poszanowanie odmienności, godności i dialogiczność pojętą jako wartość. Z tego punktu widzenia aksjologia relacji nabiera szczególnego znaczenia, jak również zasługuje na nieredukcyjne rozpoznanie. Być może dlatego wszelkie behawioralne ujęcia problematyki komunikacji międzykulturowej gubią podstawowe ich atrybuty, wśród których nawet nie tyle wzajemne uczenie się i wymiana, bo to nie jest specyficzną cechą interakcji ludzi, ale otwartość, empatia, poszanowanie godności osób i wspólnot, wrażliwość, intencjonalność i podmiotowość stanowią o jej celu. „Celem komunikacji międzykulturowej - pisze Autor - jest po pierw- 
sze zrozumienie odmienności, po drugie nabycie umiejętności dialogowej interakcji, po trzecie wreszcie rozwój tożsamości grupowej poprzez relacje o charakterze symbiotycznym" (s. 158).

Postawą zrozumienia odmienności są jednak fundamentalne predyspozycje. „Na te predyspozycje w szczególności składają się: po pierwsze, elementy wiedzy o odmienności kulturowej; po drugie bazowe reakcje na odmienność kulturową, związane z akceptacją bądź odrzuceniem sytuacji nacechowanych istnieniem zróżnicowania kulturowego; po trzecie samoocena dotycząca postaw jednostek wobec odmienności kulturowej i wreszcie po czwarte otwarcie (wrażliwość) na odmienność kulturową" (s. 164). Powyższy cytat eksponuje więc rolę „bazowych reakcji”, które podobnie jak Autor podkreślała także Kłoskowska oraz wielu innych współczesnych, humanistycznie zorientowanych badaczy kultury, jak np. Tadeusz Paleczny w środowisku krakowskiego Instytut Studiów Międzykulturowych UJ, Rafał Wiśniewski w swych studiach nad kulturą realizowanych w UKSW, Elżbieta Hałas w swych studiach nad interakcjonizmem symbolicznym w Instytucie Socjologii UW, czy obecnie Dariusz Wadowski, kontynuator myśli Leona Dyczewskiego w strukturach KUL. Mirosław Sobecki, jako pedagog, doskonale wpisuje się w socjologiczny i kulturologiczny kontekst współczesnej polskiej refleksji o wielorakich potencjałach komunikacji międzykulturowej. Wszyscy ci badacze uznają system wartości za fundamentalny element pojmowania tak kultury, jak i kompetencji. Recenzowana książka bliska jest wszystkim walorom interakcyjnego rozumienia komunikacji z silnym komponentem aksjologicznym, jaki podkreśla wielokrotnie przywoływany w pracy Jerzy Nikitorowicz, który synchronizuje różne dziedziny rozwojowego podejścia do komunikacji międzykulturowej.

Ważnym komponentem pracy są niewątpliwie własne badania empiryczne, które weryfikują wiele wcześniej postawionych hipotez. Ich niezaprzeczalną wartością jest nie tylko spójność z wcześniej analizowanymi kwestiami horyzontu badawczego książki, ale także ukierunkowanie dalszych, szczegółowych kwestii metodologii i metodyki badań. W warunkach narastania zróżnicowań kulturowych w wymiarze konkretnych regionów, środowisk, ale także instytucji narasta potrzeba gromadzenia doświadczeń w diagnozowaniu kompetencji komunikacyjnych dla celów polityki społecznej, publicznej i edukacyjnej, ale także zarządzania międzykulturowego, bezpieczeństwa wewnętrznego czy też regionalnych strategii rozwoju.

Prezentowana praca ze wszystkich wymienionych względów stanowi bardzo wartościową, unikalną wręcz w polskiej literaturze przedmiotu pozycję, która integruje wiele wątków poruszanych odrębnie na gruncie nauk spo- 
łecznych, humanistycznych i nauk o kulturze. Praca konsekwentnie realizuje przyjęty sposób rozumienia komunikacji, opierając się na eksponowaniu współczesnego paradygmatu ujęć interakcyjnych, rozwojowych i kontekstualnych. Zasadnicza teza o potrzebie „inkulturacji” badań nad komunikacją międzykulturową zyskuje niewątpliwie poważną argumentację, ukazując konkretne walory zagłębienia się w potencjały dziedzictwa kulturowego synergetycznej kultury narodów i regionów pogranicza Polski, Litwy, Białorusi i Ukrainy.

Leszek Korporowicz 